\title{
Evaluation of Anti-inflammatory, Analgesic, and Antipyretic Activities of Pseuderanthemum palatiferum
}

\author{
Kannika Inchab $^{1,2}$, Parirat Khonsung ${ }^{1 *}$, Natthakarn Chiranthanut ${ }^{1}$, \\ Puongtip Kunanusorn ${ }^{1}$, Ampai Panthong ${ }^{1}$, and Seewaboon Sireeratawong1 \\ ${ }^{I}$ Department of Pharmacology, Faculty of Medicine, Chiang Mai University, \\ Chiang Mai 50200, Thailand \\ ${ }^{2}$ Department of Pharmaceutical Care, Faculty of Pharmacy, Payap University, \\ Chiang Mai 50000, Thailand \\ *Corresponding author.E-mail: wparirat@yahoo.com \\ https://doi.org/10.12982/CMUJNS.2019.0027
}

\begin{abstract}
The objectives of this study were to evaluate the anti-inflammatory, analgesic, and antipyretic activities of water extract from fresh leaves of Pseuderanthemum palatiferum (WEPP).The anti-inflammatory activity of WEPP was evaluated in ethylphenylpropiolate (EPP)-induced ear edema, carrageenan-induced paw edema, arachidonic acid (AA)-induced paw edema, and cotton pellet-induced granuloma experiments. Acetic acid-induced writhing and tail-flick experiments were conducted to evaluate analgesic activity. Finally, antipyretic activity was evaluated in yeast-induced hyperthermia model. WEPP showed the anti-inflammatory activity and the analgesic activity but without antipyretic property. WEPP (2 mg/ear) significantly inhibited edema thickness induced by EPP (75\%). Oral administration of WEPP (600 $\mathrm{mg} / \mathrm{kg}$ ) significantly inhibited paw edema induced by carrageenan (57\%), and arachidonic acid (47\%). WEPP (600 $\mathrm{mg} / \mathrm{kg})$ did not significantly reduce the transudative weight, granuloma weight, and alkaline phosphatase activity in cotton pellet-induced granuloma formation model. The anti-inflammatory property of WEPP demonstrated on the acute phase and not on the chronic phase of inflammation. WEPP oral administration $(150,300$, and $600 \mathrm{mg} / \mathrm{kg}$ ) significantly reduced the writhing response induced by acetic acid by $21 \%, 57 \%$, and $79 \%$, respectively. In tail-flick test, WEPP slightly increased the reaction time of rats (25\%). The analgesic activity of WEPP may act via peripheral pathway. The antipyretic effect of WEPP $(600 \mathrm{mg} / \mathrm{kg})$ was not observed in yeast-induced hyperthermia model. WEPP displays an anti-inflammatory effect and has a prominent analgesic effect on the peripheral system.
\end{abstract}


Keywords: Pseuderanthemum palatiferum, Anti-inflammation, Analgesic, Acetic acid, Tail-flick, Antipyretic

\section{INTRODUCTION}

Inflammation is a complex defense reaction of live tissues to injury and has considerable impact on health and lifestyles. The current anti-inflammatory drugs, predominantly the traditional non-steroidal anti-inflammatory drugs (NSAIDs) and cyclooxygenase-2 (COX-2) selective inhibitors, have been used for centuries in the management of inflammation. There are several reports of their noticeable adverse effects including nausea, vomiting, dyspepsia, abdominal pain, ulcers or bleeding, hypertension, edema, fluid retention, and rarely congestive heart failure (CHF) and myocardial infarction (Sostres et al., 2010). Hence, there has been nowadays an increasing demand to search for less toxic anti-inflammatory drugs originating from natural products.

Pseuderanthemum palatiferum Nees Radlk, a shrub in Acanthacea family, has been called as Hoanngoc in Vietnam and Payawanorn in Thai. The leaves of $P$. palatiferum have been use as a folk medicine for relieving pain, headache, inflammation, stomach-ache, gastrointestinal disturbances, colitis, diarrhea, nephritis and hypertension (Dieu et al., 2005; Khonsung et al., 2011).

The constituents found in leaves of $P$. palatiferum are kaempferol, salicylic acid, phytol, stigmasterol, $\beta$-sitosterol, apigenin, lysine, threonine, methionine, calcium, potassium, iron, magnesium, 4-ethyl-2-methoxyphenol, megastigmatrienone, 1,2,4-triethyl-5-methyl-benzene, 2-pyrrolidinone, 2-pipridinone, octadecatrienoic acid methyl ester, and hexadecanoic acid (Khonsung et al., 2011; Mai et al., 2011; Petsangkrit \& Kittipongpatana, 2015).

Recently, the hypotensive and bradycardic effects of the water extract of $P$. palatiferum in the in vivo and in vitro models have been confirmed. Furthermore, the water extract of $P$. palatiferum shows the protective effect in gastric ulcer models (Khonsung et al., 2011; Inchab et al., 2018).

In the past decades, the water extract of $P$. palatiferum is a favorite preparation for the treatment of acute inflammation due to its improvement on swelling (Dieu et al., 2005; Khonsung et al., 2011). Although this formula has been widely used to treat inflammation with high efficiency, little is known about its mechanism of action. In Thai traditional medicine, the natural products with an anti-inflammatory effect could be used in combination with NSAIDs in order to reduce some of the unwanted adverse effects associated with NSAIDs, and this approach enables to decrease dosages of these medications without affecting efficacy. 
The evaluation of the anti-inflammatory, antinociceptive and antipyretic activities of the water extract from $P$. palatiferum leaves (WEPP) in animal models is therefore essential, in order to provide some valuable information on the public health utilization.

\section{Materials}

\section{MATERIALS AND METHODS}

The fresh leaves of $P$. palatiferum were collected from Chiang Mai, Thailand. The voucher specimen no. 42335 was authenticated and deposited at Queen Sirikit Botanic Garden Herbarium, Chiang Mai, Thailand. The fresh leaves were chopped and immersed with distilled water at room temperature for 1 day. The filtrate was collected, evaporated and lyophilized consecutively until dry. The yield of WEPP was approximately $6 \%(\mathrm{w} / \mathrm{w})$.

\section{Experimental animals}

Male Swiss albino mice and Sprague-Dawley rats were obtained from the National Laboratory Animal Center, Mahidol University, Thailand. All animals were kept in standard room $\left(24 \pm 1{ }^{\circ} \mathrm{C}, 12 \mathrm{~h}\right.$ lightdark cycle) with free access to water and standard diet. All animal care and procedures were approved by the ethical committee for Laboratory Animal Unit, Faculty of Medicine, Chiang Mai University, Thailand (no. 20/2014).

\section{Anti-inflammatory activity}

Ethyl phenylpropiolate (EPP)-induced ear edema. Nine SpragueDawley rats $(40-60 \mathrm{~g})$ were randomly divided into 3 groups ( $\mathrm{n}=6$ ears/ group). EPP in chloroform was topically applied both ears to the outer and inner surfaces (1 mg/ear). The chloroform (vehicle control), WEPP (2 mg/ ear) or ibuprofen $(1 \mathrm{mg} /$ ear) was applied to the ears prior to EPP application. The ear thickness was measured with the digital vernier calipers before and at 15, 30, 60 and $120 \mathrm{~min}$ after the induction of inflammation. The ear edema inhibition of test substances was calculated (Brattsand et al., 1982).

\section{Carrageenan-induced hind paw edema in rats}

Rats, weighing 100-120 g, were randomly divided into 6 groups $(\mathrm{n}=6$ rats/group). Carrageenan $(0.05 \mathrm{~mL}, 1 \% \mathrm{w} / \mathrm{v}$ in NSS) was intradermal injected into the plantar side of the right hind paw of the rats. Ibuprofen $(100 \mathrm{mg} / \mathrm{kg}$, p.o. $)$ or WEPP $(150,300$, and $600 \mathrm{mg} / \mathrm{kg}$, p.o.) was pretreated $1 \mathrm{~h}$ before carrageenan injection. The edema of the right hind paw was evaluated using a plethysmometer 
(model 7150, Ugo Basile, Italy) before and at 1, 3 and $5 \mathrm{~h}$ after carrageenan injection (Winter et al., 1962).

\section{Arachidonic acid (AA)-induced hind paw edema in rats}

The procedure to induce hind paw edema in rats was similar to the previous method by an intradermal injection of AA $(0.1 \mathrm{~mL}, 0.5 \% \mathrm{w} / \mathrm{v}$ in $0.2 \mathrm{M}$ carbonate buffer) instead of carrageenan. Ibuprofen $(100 \mathrm{mg} / \mathrm{kg}$, p.o.) or WEPP $(150,300$, and $600 \mathrm{mg} / \mathrm{kg}$, p.o. $)$ was given to the rats $2 \mathrm{~h}$ prior to AA injection. The same equipment was used to evaluate the edema volume before and at $1 \mathrm{~h}$ after AA injection (DiMartino et al., 1987).

\section{Cotton pellet-induced granuloma formation in rats}

Rats were randomly divided into 4 groups (200-250 g, $\mathrm{n}=6$ rats/group). The rats under anesthesia were implanted subcutaneously with 2 sterilized cotton pellets $(19-21 \mathrm{mg})$, one on each side of the abdomen of the rat. The rats in each group were given distilled water $(0.5 \mathrm{~mL} / 100 \mathrm{~g}$, p.o.), ibuprofen $(100 \mathrm{mg} /$ $\mathrm{kg} /$ day, p.o.), prednisolone (5 mg/kg/day, p.o.) or WEPP (600 mg/kg/day, p.o.), respectively once a day for 7 days. Each rat was anaesthetized on the eighth day and the blood was collected from the heart for determination of total protein and alkaline phosphatase (ALP) activity. The implanted pellets were dissected and measured for the wet and the dry weights (dried at $60^{\circ} \mathrm{C}$ for $18 \mathrm{~h}$ ). The transudative weight and the granuloma inhibition were calculated. The body weight and dry weight of the thymus gland were also recorded (Swingle and Shideman, 1972).

\section{Analgesic test}

Acetic acid-induced writhing response in mice. A single dose of acetic acid $(0.1 \mathrm{~mL} / 10 \mathrm{~g}$ body weight, $0.75 \% \mathrm{v} / \mathrm{v}$ in NSS) was injected into the peritoneal cavity of the mice (30-40 g, 5 groups each containing of 6 mice). Distilled water $(0.1 \mathrm{~mL} / 10 \mathrm{~g}$, p.o.), ibuprofen $(100 \mathrm{mg} / \mathrm{kg}$, p.o.) or WEPP $(150,300$, and $600 \mathrm{mg} / \mathrm{kg}$, p.o.) was given $1 \mathrm{~h}$ before acetic acid injection. The number of writhes was recorded for 15 min beginning from 5 min after the acetic acid injection (Nakamura et al., 1986).

\section{Tail-flick test}

The tail-flick response was determined using a photocell window of the tail-flick apparatus (model 7,360, Ugo Basile, Italy). Rats weighing 180-220 g were randomly divided into 4 groups ( $\mathrm{n}=6$ rats). Each group was pretreated with distilled water $(0.5 \mathrm{~mL} / 100 \mathrm{~g}$, p.o.), codeine $(200 \mathrm{mg} / \mathrm{kg}$, p.o.), ibuprofen (100 mg/kg, p.o.) or WEPP (600 mg/kg, p.o.), respectively. Then $1 \mathrm{~h}$ later, the 
reaction time of each rat defined as the time to flick of the tail was recorded. A cut-off time of $15 \mathrm{~s}$ was set to avoid tissue damage. The reaction time was measured before and at $1 \mathrm{~h}$ after the substance administration (Gray et al., 1970). The percent inhibition was calculated using the following equation:

$$
\begin{aligned}
\text { Inhibition }(\%)= & {[\text { Test reaction time-Baseline reaction time }] * 100 } \\
& /[15-\text { Baseline reaction time }]
\end{aligned}
$$

\section{Antipyretic test}

Yeast-induced hyperthermia in rats. Hyperthermia was induced by subcutaneous injection of a single dose of yeast $(1 \mathrm{~mL} / 100 \mathrm{~g}$ body weight, $25 \% \mathrm{w} / \mathrm{v}$ in NSS) to the rats (180-220 g, 3 groups of 6 rats each). The baseline rectal temperatures were carried out using a 12-channel electric thermometer (LETICA, model TMP 812 RS, Panlab S.L., Spain). Rats which had more than a $1{ }^{\circ} \mathrm{C}$ rise from the baseline temperature at $18 \mathrm{~h}$ after yeast injection were given with distilled water, ibuprofen (100 mg/kg, p.o.) or WEPP $(600 \mathrm{mg} / \mathrm{kg}$, p.o.) depended on the groups. The rectal temperatures were repeatedly measured before and at 60, 90, and $120 \mathrm{~min}$ after treatment (Teotino et al., 1963).

\section{Statistical Analysis}

The results are shown as mean \pm standard error of the mean (S.E.M). Statistical analysis was carried out using one-way analysis of variance (ANOVA) and the post hoc least-significant difference (LSD) test. The level of statistical significance was set at $\mathrm{p}$-value less than 0.05 .

\section{RESULTS}

\section{EPP-induced ear edema in rats}

WEPP (2 mg/ear) and ibuprofen (1 mg/ear) significantly inhibited the edema thickness of the rats caused by EPP at all assessment times when compared to that of the vehicle group (Table 1). 
Table 1. Effects of WEPP and ibuprofen on EPP-induced ear edema in rats.

\begin{tabular}{|c|c|c|c|c|c|}
\hline \multirow[t]{2}{*}{ Group } & \multirow{2}{*}{$\begin{array}{c}\text { Dose } \\
\text { (mg/ear) }\end{array}$} & \multicolumn{4}{|c|}{ Edema thickness in $\mathrm{mm}$ (\% inhibition) } \\
\hline & & $15 \mathrm{~min}$ & $30 \mathrm{~min}$ & $1 \mathrm{~h}$ & $2 \mathrm{~h}$ \\
\hline Chloroform & - & $0.24 \pm 0.01$ & $0.32 \pm 0.01$ & $0.38 \pm 0.01$ & $0.28 \pm 0.02$ \\
\hline Ibuprofen & 1 & $\begin{array}{c}0.04 \pm 0.01^{*} \\
\quad(83 \%)\end{array}$ & $\begin{array}{c}0.06 \pm 0.01 * \\
\quad(81 \%)\end{array}$ & $\begin{array}{c}0.14 \pm 0.01 * \\
\quad(63 \%)\end{array}$ & $\begin{array}{c}0.11 \pm 0.01 * \\
\quad(61 \%)\end{array}$ \\
\hline WEPP & 2 & $\begin{array}{c}0.06 \pm 0.01 * \\
(75 \%)\end{array}$ & $\begin{array}{c}0.10 \pm 0.01 * \\
(69 \%)\end{array}$ & $\begin{array}{c}0.18 \pm 0.01 * \\
(53 \%)\end{array}$ & $\begin{array}{c}0.12 \pm 0.01 * \\
\quad(57 \%)\end{array}$ \\
\hline
\end{tabular}

Note: Values are expressed as mean \pm S.E.M. $(\mathrm{n}=6) . *$ Significantly different from the control group $(P<0.05)$.

\section{Carrageenan-induced hind paw edema in rats}

Ibuprofen (100 mg/kg, p.o.) and WEPP (300 and $600 \mathrm{mg} / \mathrm{kg}$, p.o.) significantly inhibited hind paw edema formation at all assessment times (Table 2). A lower dose of WEPP $(150 \mathrm{mg} / \mathrm{kg})$ significantly inhibited the paw edema of the rats only at 1 and $3 \mathrm{~h}$ of the evaluating period.

Table 2. Effects of WEPP and ibuprofen on carrageenan-induced hind paw edema in rats.

\begin{tabular}{|c|c|c|c|c|c|c|c|}
\hline \multirow{3}{*}{ Group } & \multirow[b]{3}{*}{$\begin{array}{c}\text { Dose } \\
\text { (mg/ } \\
\text { kg) }\end{array}$} & \multicolumn{6}{|c|}{ Time after carrageenan injection } \\
\hline & & \multicolumn{2}{|c|}{$1 \mathrm{~h}$} & \multicolumn{2}{|c|}{$3 \mathbf{h}$} & \multicolumn{2}{|c|}{$5 \mathrm{~h}$} \\
\hline & & $\begin{array}{c}\text { Edema } \\
\text { volume } \\
(\mathrm{mL})\end{array}$ & $\begin{array}{c}\% \\
\text { inhibition }\end{array}$ & $\begin{array}{c}\text { Edema } \\
\text { volume } \\
\text { (mL) }\end{array}$ & $\begin{array}{c}\% \% \\
\text { inhibition }\end{array}$ & $\begin{array}{c}\text { Edema } \\
\text { volume } \\
(\mathrm{mL})\end{array}$ & $\begin{array}{c}\% \\
\text { inhibition }\end{array}$ \\
\hline Control & - & $\begin{array}{c}0.31 \pm \\
0.02\end{array}$ & - & $\begin{array}{c}0.61 \pm \\
0.05\end{array}$ & - & $\begin{array}{c}0.46 \pm \\
0.02\end{array}$ & - \\
\hline Ibuprofen & 100 & $\begin{array}{c}0.16 \pm \\
0.02 *\end{array}$ & 48 & $\begin{array}{c}0.26 \pm \\
0.02 *\end{array}$ & 56 & $\begin{array}{c}0.24 \pm \\
0.03^{*}\end{array}$ & 54 \\
\hline WEPP & 150 & $\begin{array}{c}0.17 \pm \\
0.01 *\end{array}$ & 45 & $\begin{array}{c}0.44 \pm \\
0.03 *\end{array}$ & 27 & $\begin{array}{c}0.41 \pm \\
0.02\end{array}$ & 10 \\
\hline WEPP & 300 & $\begin{array}{c}0.15 \pm \\
0.03 *\end{array}$ & 51 & $\begin{array}{l}0.40 \pm \\
0.05^{*}\end{array}$ & 33 & $\begin{array}{l}0.36 \pm \\
0.05^{*}\end{array}$ & 21 \\
\hline WEPP & 600 & $\begin{array}{c}0.13 \pm \\
0.02 *\end{array}$ & 57 & $\begin{array}{l}0.35 \pm \\
0.03 *\end{array}$ & 41 & $\begin{array}{l}0.29 \pm \\
0.01 *\end{array}$ & 36 \\
\hline
\end{tabular}

Note: Values are expressed as mean \pm S.E.M. $(\mathrm{n}=6) .{ }^{*}$ Significantly different from the control group $(P<0.05)$.

\section{AA-induced hind paw edema in rats}

Rats which pretreated with prednisolone $(5 \mathrm{mg} / \mathrm{kg}$, p.o.) significantly showed the less edema volume of the paws when compared to the other rats 
(Table 3). The percent inhibition of hind paw edema was ordered from that of prednisolone group (59\%), WEPP group $(600 \mathrm{mg} / \mathrm{kg}, 47 \%)$ and ibuprofen group (31\%), respectively.

Table 3. Effects of WEPP, ibuprofen and prednisolone on AA-induced hind paw edema in rats.

\begin{tabular}{lccc}
\hline \multicolumn{1}{c}{ Group } & Dose (mg/kg) & $\begin{array}{c}\text { Edema volume at } \mathbf{1} \mathbf{h} \\
(\mathbf{m L})\end{array}$ & \% inhibition \\
\hline Control & - & $0.16 \pm 0.02$ & - \\
Ibuprofen & 100 & $0.11 \pm 0.01$ & 31 \\
Prednisolone & 5 & $0.07 \pm 0.01^{*}$ & 59 \\
WEPP & 150 & $0.15 \pm 0.03$ & 9 \\
WEPP & 300 & $0.13 \pm 0.02$ & 18 \\
WEPP & 600 & $0.09 \pm 0.01^{*}$ & 47 \\
\hline
\end{tabular}

Note: Values are expressed as mean \pm S.E.M. $(\mathrm{n}=6) .{ }^{*}$ Significantly different from the control group $(P<0.05)$.

\section{Cotton pellet-induced granuloma formation in rats}

As shown in Table 4, WEPP (600 mg/kg/d, p.o.) and ibuprofen $(100 \mathrm{mg} / \mathrm{kg} /$ day, p.o.) did not significantly reduce the transudative weight and the granuloma weight when compared to those of the control group, whereas, prednisolone $(5 \mathrm{mg} / \mathrm{kg} / \mathrm{d}$, p.o.) significantly reduced the weight of both parameters as well as the ALP activity in the blood. It was also found that the dry thymus weight and the body weight gain were not significantly different among groups (control, ibuprofen, and WEPP groups), except in the prednisolone group which evidenced a significant decrease both of the dry thymus weight and the body weight gain from the control group. 


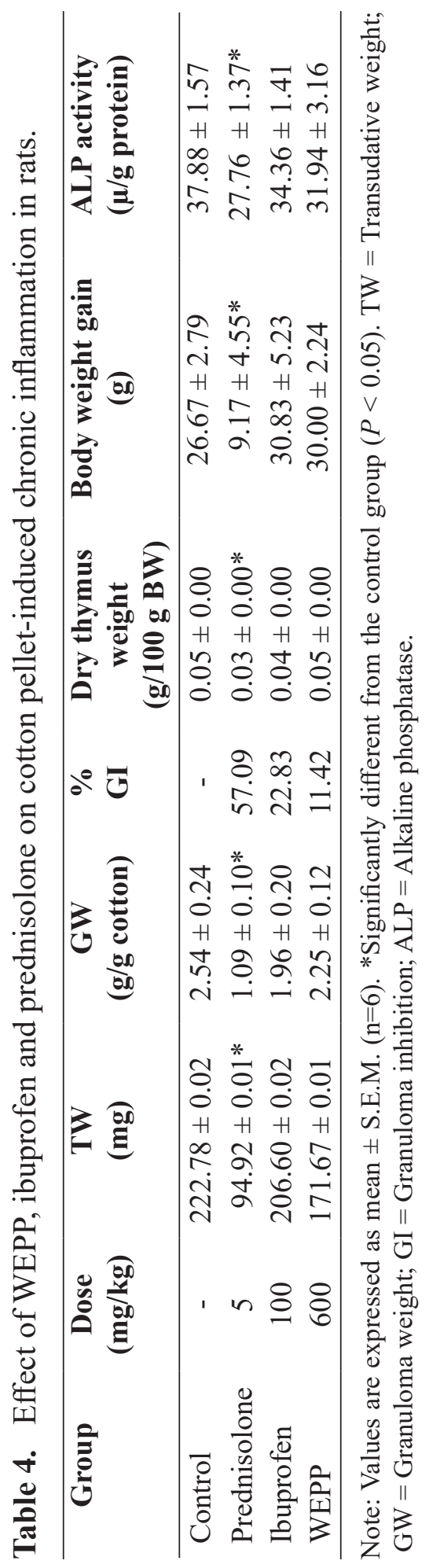




\section{Acetic acid-induced writhing response in mice}

As shown in Table 5, rats which received WEPP $(150,300$ or $600 \mathrm{mg} / \mathrm{kg}$, p.o.) or ibuprofen $(100 \mathrm{mg} / \mathrm{kg}$, p.o.) showed a significant reduction of the writhes of the abdomen caused by acetic acid injection when compared to that of the control group. The writhing response inhibition of WEPP was a dose-dependent manner.

Table 5. Effects of WEPP and ibuprofen on acetic acid-induced writhing response in mice.

\begin{tabular}{lccc}
\hline Group & Dose (mg/kg) & Number of writhes & \% inhibition \\
\hline Control & - & $28 \pm 1.41$ & - \\
Ibuprofen & 100 & $10 \pm 0.67^{*}$ & 64 \\
WEPP & 150 & $22 \pm 0.99^{*}$ & 21 \\
WEPP & 300 & $12 \pm 0.63^{*}$ & 57 \\
WEPP & 600 & $6 \pm 0.54^{*}$ & 79 \\
\hline
\end{tabular}

Note: Values are expressed as mean \pm S.E.M. $(\mathrm{n}=6)$. *Significantly different from the control group $(P<0.05)$.

\section{Tail-flick test}

Pretreatment the rats with WEPP (600 mg/kg, p.o.), ibuprofen $(100 \mathrm{mg} /$ $\mathrm{kg}$, p.o.) or codeine (200 mg/kg, p.o.) significantly increased the reaction time (Table 6). The highest percent inhibition was observed in the rats which received codeine.

Table 6. Effect of WEPP, ibuprofen and codeine on tail-flick test in rats.

\begin{tabular}{lcccc}
\hline Group & $\begin{array}{c}\text { Dose } \\
(\mathbf{m g} / \mathbf{k g})\end{array}$ & $\begin{array}{c}\text { Baseline } \\
\text { reaction time } \\
(\mathbf{s e c})\end{array}$ & $\begin{array}{c}\text { Test reaction } \\
\text { time } \\
\mathbf{( s e c )}\end{array}$ & \% inhibition \\
\hline Control & - & $3.05 \pm 0.10$ & $3.30 \pm 0.10$ & \\
Ibuprofen & 100 & $3.08 \pm 0.07$ & $4.42 \pm 0.17^{*}$ & 17 \\
Codeine & 200 & $3.05 \pm 0.06$ & $7.60 \pm 0.06^{*}$ & 64 \\
WEPP & 600 & $3.06 \pm 0.05$ & $5.00 \pm 0.29^{*}$ & 25 \\
\hline
\end{tabular}

Note: Values are expressed as mean \pm S.E.M. $(\mathrm{n}=6)$. *Significantly different from the control group $(P<0.05)$. 


\section{Yeast-induced hyperthermia in rats}

Ibuprofen $(100 \mathrm{mg} / \mathrm{kg}$, p.o.) significantly reduced the body temperature of the hyperthermic rats at all assessment times, whereas the antipyretic effect of WEPP (600 mg/kg, p.o.) was not observed in this model (Table 7).

Table 7. Effect of WEPP and ibuprofen on Yeast-induced hyperthermia in rats.

\begin{tabular}{lccccc}
\hline \multirow{2}{*}{ Group } & \multicolumn{5}{c}{ Rectal temperature $\left({ }^{\circ} \mathbf{C}\right)$} \\
\cline { 2 - 6 } & Baseline & $\begin{array}{c}\mathbf{1 8} \text { h after } \\
\text { yeast } \\
\text { injection }\end{array}$ & $\mathbf{6 0}$ & $\mathbf{6 0}$ & $\mathbf{1 2 0}$ \\
\hline Distilled water & $37.65 \pm 0.06$ & $39.17 \pm 0.15$ & $38.88 \pm 0.24$ & $38.75 \pm 0.22$ & $38.62 \pm 0.17$ \\
$\begin{array}{l}\text { Ibuprofen } \\
(100 \mathrm{mg} / \mathrm{kg})\end{array}$ & $37.95 \pm 0.10$ & $39.15 \pm 0.17$ & $38.00 \pm 0.21$ & $37.85 \pm 0.20^{*}$ & $37.80 \pm 0.20^{*}$ \\
$\begin{array}{l}\mathrm{WEPP} \\
(600 \mathrm{mg} / \mathrm{kg})\end{array}$ & $37.91 \pm 0.09$ & $39.15 \pm 0.10$ & $38.60 \pm 0.11$ & $38.50 \pm 0.11$ & $38.30 \pm 0.10$ \\
\hline
\end{tabular}

Note: Values are expressed as mean \pm S.E.M. $(\mathrm{n}=6)$. $*$ Significantly different from the control group $(P<0.05)$.

\section{DISCUSSION}

Our results confirmed that water extract of $P$. palatiferum (WEPP) exhibited an anti-inflammatory effect on acute phase of inflammation. EPPinduced ear edema, carrageenan-induced paw edema and AA-induced hind paw edema in rats are classical models of acute inflammation, which frequently been used to identification of a new lead compound (Winter et al., 1962; Brattsand et al., 1982; DiMartino et al., 1987). EPP is a strong stimulant that activates the release of pro-inflammatory mediators, such as histamine, serotonin, bradykinin and prostaglandins (PGs) which increase the vascular permeability and inflammatory cell infiltration (Manouze et al., 2017). WEPP was screened for anti-inflammatory effect in EPP-induced ear edema model.

The carrageenan injection involves three phases of inflammation that causes the paw edema: an initial phase $(0-1.5 \mathrm{~h})$ is attributed to release of histamine and serotonin; a second phase $(1.5-2.5 \mathrm{~h})$ is attributed to release of bradykinin; a third phase (2.5-6 h) is attributed to the synthesis of PGs (Panthong et al., 2007). The significant paw edema inhibition of WEPP at all assessment time in this model was suggested that the mechanism of anti-inflammatory effect of WEPP may partly involve with 
the release or the synthesis of the predominant pro-inflammatory mediators synthesized and/or released during these periods i.e. COX pathway products.

AA-induced hind paw edema is used to evaluate the lipoxygenase inhibitors or the dual inhibitors (COX and LOX inhibitors) (Mukarram Shah, 2015). Additionally, prednisolone (a steroid drug) which inhibits phospholipase A2, showed a significant edema inhibition of the paw in this study. WEPP at the dose of $600 \mathrm{mg} / \mathrm{kg}$ also exhibited an anti-inflammatory effect on AAinduced hind paw edema. The mechanism of anti-inflammatory effect of WEPP may relate to the lipoxygenase pathway. Thus, the mechanism of antiinflammatory effect of WEPP may involve with COX and LOX pathway.

Cotton pellet-induced granuloma formation in rat is a standard model for chronic inflammation (Sarraf and Sneller, 2005). In chronic inflammatory response, accumulation of fibroblasts and the persistence of inflammatory cells lead to the release of pro-inflammatory mediators, free radicals, and lysosomal enzymes such as ALP which result in subsequent tissue injury (Manouze et al., 2017). Macrophages accumulate in layers surrounding the problematical material and sometimes form giant cells. The structure is formed, with layers of macrophage surrounding a central core, called a granuloma. In the early phase of inflammation resulting from an increased vascular permeability, the extravascular fluid which accumulates is called transudate. Transudate has a low protein concentration and consists primarily of lymphocytes, macrophages, and mesothelial cells (Sireeratawong et al., 2013). Prednisolone significantly reduced transudative, granuloma weights and ALP activity (Partovi et al., 2018), whereas, WEPP and ibuprofen did not show any effects on these parameters. Moreover, prednisolone reduced thymus weight and body weight gain. These effects of prednisolone may be due to peripheral catabolism of lymphoid and connective tissues (Schimmer and Parker, 2006). WEPP did not influence the thymus weight and the body weight gain. Thus, it seems unlikely that WEPP had a steroid-like effect. Previous study has reported that the ethanol extract of Pseuderanthemum palatiferum has potent anti-transudative and anti-granuloma properties (Khumpook et al. 2013). Additionally, the ethanol extract suppressed proinflammatory cytokines, TNF- $\alpha$ and IL-6, expression by LPS-activated mouse peritoneal macrophages (Sittisart et al., 2016). However, differences in quality and quantity of composition between water and ethanol extracts are expected to exist. All results clearly demonstrated the anti-inflammatory property of WEPP on the acute phase and not on the chronic phase of inflammation.

The results from antinociceptive activity tests revealed the analgesic activity and possible mechanism of WEPP. In acetic acid-induced writhing response model, acetic acid is an irritant which causes nociception through 
interplay of complex mechanisms involving the inflammatory mediators such as histamine, serotonin, bradykinin, substance $\mathrm{P}$ and PGs that stimulate pain nerve endings (Nakamura et al., 1986; Raj, 1996). WEPP showed analgesic activity in a dose dependent manner. The higher dose of WEPP produced a similar analgesic action to ibuprofen. The tail-flick test was performed to investigate the central analgesic activity of WEPP. Codeine, a centrally acting analgesic, caused a significant increase the reaction time in the tail-flick test. WEPP and ibuprofen increased the reaction time but the percent inhibition of WEPP and ibuprofen was lower than that of codeine. The results showed that the analgesic activity of WEPP probably mediated through peripheral mechanism.

An injection of yeast to the rats results in the increase of the body temperature (Janeway and Travers, 1999; Murphy and Ward, 2005; Sireeratawong et al., 2012). Ibuprofen can pass through the blood brain barrier (BBB) of the CNS to inhibit PGs synthesis in hypothalamic area which exhibits its antipyretic effect (Ganong, 2001). In this study, ibuprofen could significantly reduce the body temperature of the hyperthermic rats, whereas WEPP could not show this effect. The results from tail-flick test and yeast-induced hyperthermia test assumed that WEPP might not be able to cross the BBB to exert central analgesic and antipyretic activities.

\section{CONCLUSION}

WEPP displays an anti-inflammatory effect and has a prominent analgesic effect on the peripheral system. Further study of molecular interactions between the proteins and ligands using molecular modelling is needed.

\section{REFERENCES}

Bessey, O.A., Lowry, O.H., and Brock, M.J. 1946. A method for the rapid determination of alkaline phosphates with five cubic millimeters of serum. Journal of Biological Chemistry. 164: 321-329.

Brattsand, R., Thalen, A., Roempke, K., Kallstrom, L., and Gruvstad, E. 1982. Influence of 16 alpha, 17 alpha-acetal substitution and steroid nucleus fluorination on the topical to systemic activity ratio of glucocorticoids. Journal of Steroid Biochemistry. 16(6): 779-786.

Carlson, R. P., O’Neill-Davis, L., Chang, J., and Lewis, A. J. 1985. Modulation of mouse ear edema by cyclooxygenase and lipoxygenase inhibitors and other pharmacologic agents. Agents Actions. 17(2): 197-204. 
Dieu, H.K., Loc, C.B., Yamasaki, S., and Hirata, Y. 2005. The ethnobotanical and botanical study on Pseuderanthemum palatiferum as a new medicinal plant in the mekong delta of Vietnam. Japan Agricultural Research Quarterly. 39(3): 191-196. https://doi.org/10.6090/jarq.39.191

DiMartino, M.J., Campbell, G.K., Jr., Wolff, C.E., and Hanna, N. 1987. The pharmacology of arachidonic acid-induced rat paw edema. Agents Actions. 21(3-4): 303-305. https://doi.org/10.1007/BF01966498

Ganong, W.F. 2001. Functions of the nervous system: central regulation of visceral function. In: Ganong, W.F., editor. Review of medical physiology. $20^{\text {th }}$ ed. McGraw-Hill, New York. p.245-247.

Gray, W.D., Osterberg, A.C., and Scuto, T.J. 1970. Measurement of the analgesic efficacy and potency of pentazocine by the D'Amour and Smith method. Journal of Pharmacology and Experimental Therapeutics. 172(1): 154-162.

Inchab, K., Khonsung, P., Chiranthanut, N., Kunanusorn, P., Potikanond, S., Chansakaow, S., and Sireeratawong, S. 2018. Anti-gastric ulcer activity of the water extract from payawanorn (Pseuderanthemum Palatiferum). Journal of Health Science and Medical Research. 36(2): 89-95. https://doi.org/10.31584/jhsmr.v36i2.1

Janeway, C.A., Jr., and Travers, P. 1999. Host defense against infection. In: Walport, M., Capra, J., editors. Immunobiology: the immune system I health and disease. $4^{\text {th }}$ ed. Garland Publishing, New York. p.363-415. Khonsung, P., Panthong, A., Chiranthanut, N., and Intahphuak, S. 2011. Hypotensive effect of the water extract of the leaves of Pseuderanthemum palatiferum. Journal of Natural Medicines. 65(3): 551-558. https://doi. org/10.1007/s11418-011-0540-z

Khumpook T., Chomdej S., Saenphet S., Amornlerdpison D., and Saenphet K. 2013. Anti-inflammatory activity of ethanol extract from the leaves of Pseuderanthemum palatiferum (Nees) Radlk. Chiang Mai Journal of Science. 40(3): 321-331.

Mai, H.D., Minh, H.N., Pham, V.C., Bui, K.N., Nguyen, V.H., and Chau, V.M. 2011. Lignans and other constituents from the roots of the Vietnamese medicinal plant Pseuderanthemum palatiferum. Planta Medica. 77(9): 951-954. https://doi.org/10.1055/s-0030-1250683

Manouze, H., Bouchatta, O., Gadhi, A. C., Bennis, M., Sokar, Z., and Ba-M'hamed, S. 2017. Anti-inflammatory, antinociceptive, and antioxidant activities of methanol and aqueous extracts of Anacyclus pyrethrum roots. Frontiers in Pharmacology. 8: 598. https://doi.org/10.3389/fphar.2017.00598 
Mukarram Shah, S.M. 2015. A possible anti-inflammatory mechanism of ethyl acetate extracts of Teucrium stocksianum Bioss. BMC Complementary and Alternative Medicine. 15: 299. https://doi.org/ 10.1186/s12906-015-0834-X

Murphy, H., and Ward, P. 2005. Inflammation. In: Rubin, E., editor. Rubin's Pathology: Clinicopathologic Foundations of Medicine. $4^{\text {th }}$ ed. Lippincott Williams \& Wilkins, Philadelphia. p. 40-83.

Nakamura, H., Shimoda, A., Ishii, K., and Kadokawa, T. 1986. Central and peripheral analgesic action of non-acidic non-steroidal anti-inflammatory drugs in mice and rats. Archives Internationales de Pharmacodynamie et de Thérapie. 282(1): 16-25.

Panthong, A., Supraditaporn, W., Kanjanapothi, D., Taesotikul, T., and Reutrakul, V. 2007. Analgesic, anti-inflammatory and venotonic effects of Cissus quadrangularis Linn. Journal of Ethnopharmacology. 110(2): 264-270. https://doi.org/10.1016/j.jep.2006.09.018

Partovi, S.E., Mus, F., Gutknecht, A.E., Martinez, H.A., Tripet, B.P., Lange, B.M., and Peters, J.W. 2018. Coenzyme M biosynthesis in bacteria involves phosphate elimination by a functionally distinct member of the aspartase/ fumarase superfamily. Journal of Biological Chemistry. 293(14): 52365246. https://doi.org/10.1074/jbc.RA117.001234

Petsangkrit, N., and Kittipongpatana, N. 2015. Establishment of Pseudoranthemum palatiferum (Ness) Radlk callus culture and screening of secondary metabolite production. International Journal of Pharmacy and Pharmaceutical Sciences. 8(1): 275-280.

Raj, P.P. 1996. Pain mechanisms. In: Raj, P.P., editor Pain medicine: A comprehensive review. Mosby-Year Book, Missouri. p.12-23.

Sarraf, P., and Sneller, M.C. 2005. Pathogenesis of Wegener's granulomatosis: current concepts. Expert Reviews in Molecular Medicine. 7(8): 1-19. https://doi.org/10.1017/s146239940500921x

Schimmer, B.P., and Parker, K.L. 2006. Adrenocorticotropic hormone; Adrenocortical steroids and their synthetic analogs; Inhibitors of synthesis and actions of adrenocortical hormones. In: Brunton, L., Lazo, J., Parker, K., editors. Goodman \& Gilman,s the pharmacological basis of therapeutics. $11^{\text {th }}$ ed. McGraw-Hill, New York. p.1587-1612. Sireeratawong, S., Khonsung,P.,Piyabhan,P., Nanna,U., Soonthornchareonnon, N., and Jaijoy, K. 2012. Anti-inflammatory and anti-ulcerogenic activities of Chantaleela recipe. African Journal of Traditional, Complementary and Alternative Medicines. 9(4): 485-494. 
Sireeratawong, S., Jaijoy, K., and Soonthornchareonnon, N. 2013. Evaluation of anti-inflammatory and antinociceptive activity of Triphala recipe. African Journal of Traditional, Complementary and Alternative Medicines.10(2): 246-250.

Sittisart, P., Chitsomboon, B., and Kaminski, NE. 2016. Pseudoranthemum palatiferum leaf extract inhibits the proinflammatory cytokines, TNF- $\alpha$ and IL-6 expression in LPS-activated macrophages. Food and Chemical Toxicology. 97: 11-22. https://doi.org/10.1016/j.fct.2016.08.021

Sostres, C., Gargallo, C.J., Arroyo, M.T., and Lanas, A. 2010. Adverse effects of non-steroidal anti-inflammatory drugs (NSAIDs, aspirin and coxibs) on upper gastrointestinal tract. Best Practice \& Research Clinical Gastroenterology. 24(2): 121-132. https://doi.org/10.1016/j.bpg.2009. 11.005

Swingle, K.F., and Shideman, F.E. 1972. Phases of the inflammatory response to subcutaneous implantation of a cotton pellet and their modification by certain anti-inflammatory agents. Journal of Pharmacology and Experimental Therapeutics. 183(1): 226-234.

Teotino, U.M., Friz, L.P., Gandini, A., and Dellabella, D. 1963. Thio derivatives of 2,3-dihydro-4h-1,3-benzoxazin-4-one. synthesis and pharmacological properties. Journal of Medicinal Chemistry. 6: 248-250. https://doi.org/10.1021/jm00339a007

Winter, C.A., Risley, E.A., and Nuss, G.W. 1962. Carrageenin-induced edema in hind paw of the rat as an assay for antiiflammatory drugs. Proceedings of the Society for Experimental Biology and Medicine. 111: 544-547. https://doi.org/10.3181/00379727-111-27849 